\title{
The Impact of British Industrial Revolution on a Bengal Industry
}

\author{
Siddhartha Bhadra \\ Assistant Professor, Department of Economics, M.U.C Women's College, Burdwan, West Bengal, India
}

\begin{abstract}
Bengal was probably the world's most famous producer of cotton textile for a long period of time. The manufacture of cotton goods was found in almost every village in Bengal. Numerous kinds of clothes were manufactured by the weavers of Bengal which were differentiated by various names according to the fabrics and places where they were manufactured. The cotton manufactures of Bengal can be divided into two broad categories viz., muslins and calicoes. Muslins were thinner in texture and lighter in weight than the calicoes.During the early trade of European with India by the long sea route, the calicoes and fine muslins of Bengal were well accepted by the people of the different parts of the World. Bengal textile products of different verities flooded into the European market in the seventeenth and eighteenth centuries which climbed the peak in the mid eighteenth century.

From the beginning of the eighteenth century, there were two main production centers of cotton goods in the Global context i.e. Bengal at one end and England at the other. The Bengal cotton textile industry was running under severe competition with that of England as the latter progressed rapidly after the Industrial Revolution and the English industry could able to win over Bengal's competitive edge by the turn of eighteenth century. Since then the prosperous industry of Bengal started to decay and in the first half of nineteenth century its position reached at a gloomy state.

The cause(s) of the decay of the Bengal industry are still open to debate. To clarify the disputes, this article seeks to show how far the British Industrial revolution was responsible for the decay of the prosperous cotton industry of Bengal.
\end{abstract}

Keywords: Cotton textile, decay, industrial revolution, piece-good, weaver.

\section{Introduction}

The decay of the cotton textile industry of Bengal in the first half of the nineteenth century had been narrated in many literatures of economic history. But the identification of the exact period of the decay by the economic historians is not same. N. K. Sinha,(1961, vol.I, p.180) pointed out that the decline of the industry started considerably since 1793. Dutta (1960, p. 256-57) shows that the decay started considerably since 1813. According to Twomay (1983, P. 37-57) the clear turning point of the industry from its prosperity to decline was 1830 when the Indian subcontinent had become a net importer of cloth from England. There exists a great debate about the actual cause or causes of the decay of the industry. According to different literatures, the causes were - the industrial revolution or technological innovation in England, the hostile tariff imposed on Bengal goods in England, the oppressive measures on the Bengal weavers by the Britishers, loss of market after the fall of noble courts and changes in preference on European goods of the indigenous people.

In this background, this article seeks to show how far the British Industrial revolution was responsible for the Decay of the prosperous cotton industry of Bengal. To explain this, a comparative analysis between the cotton industry of Bengal and that of England in the period under review will be discussed from the view point of technology and productivity growth.

There are three sections in what follows---

Section I compares the technology of production employed in both countries during $1757-1857$. Section II compares the productivity growth and labour cost of production between two countries in the aforesaid period. Section III is the concluding part.

The actual date of starting cotton-spinning and weaving in Bengal cannot be arrived at, though there is little doubt of its high antiquity. During the early period the trade between European with India was mainly through the long sea route. The calicoes and fine muslins of Bengal were well accepted by the people of the different parts of the World. Bengal textile products of different verities flooded into the European market in the seventeenth and eighteenth centuries, reaching a peak in the mid eighteenth century. The English cotton manufactures was the main competitor of Bengal in the World market. From the beginning of the eighteenth century, there were two main production centers of cotton goods in the Global context, Bengal at one end and 
England at the other. The Bengal cotton textile industry was running under severe competition with the cotton textile industry of England as latter progressed rapidly due to Industrial Revolution or technological innovation as a result of which the English industry could win over Bengal's competitive edge by the first half of the eighteenth century.

The technology of production of Bengal cotton textile industry was a very simple and the process of production was very crude. It was a domestic manufacture and carried on with the rudest and cheapest apparatus for which neither capital, nor mills or an assemblage of various trades was required. The cotton was separated from the seeds by a small rude hand - mill or gin, turned by women. The mill consisted of two rollers of teak wood, fluted longitudinally with five or six grooves, and revolving nearly in contact. The upper roller was turned by a handle, and the lower was carried along with it by a perpetual screw at the axis. The cotton was put in at one side, and drawn through by the revolving rollers; but the seeds, were too large to pass through the opening, were torn off, and fall down on the opposite side from the cotton (Baines, 1835, p.61).

The next operation was that of bowing the cotton to clear it from dirt and knots. A large bow, made elastic by a complication of strings, was used which was put in contact with a heap of cotton, the workman used to strike the string with a heavy wooden mallet, and its vibrations open the knots of the cotton, shake from it the dust and dirt, and raised it to a downy fleece (Baines, 1835, p.61).

After then cotton used to spin by women of Hindu community whose age were between eighteen years and thirty years. Because, after thirty years, their eye sight did not permit the spinning. The spinning was done by a wheel. Most of the household in the village had one or more spinning wheel. At their leisure hours, all the women of the household used to engage in spinning. According to Ward (Ward,1818, p.93) "women of all castes, prepare the cotton thread for the weaver, spinning the thread on a piece of ware, or a very thin rod of iron with ball of clay at one end, this they turn round with the left hand, and supply the cotton with the right. The thread is often wound upon a stick or pole and sold to the merchants or weavers. For the coarser thread, the women make use of a wheel, very similar to the English spinster, though upon a smaller construction".

After spinning weaving was the next stage. According to Taylor (Taylor, 1840, p.174), a weaver's loom was under a shed or the roof of his own house. There existed a pit in the floor to afford room for the lower part of the gear and for the weaver's legs as he sat at work. Above the loom a sort of canopy was built consisting of a mat or two, to protect the web from dust and rain dropping from the roof. One hundred and twenty six implements were used to make the fine muslin from the raw cotton. They were all made of small pieces of bamboo or reed tied together with twine or thread. The workmanship of the implements was very simple and rude and a weaver could make them himself. Although, the weaver used to purchase the readymade implements from the bazaars to save time and trouble.

After then a large proportion of woven cotton cloths were coloured by the indigenous dyers. Dyeing was an important industry as large number of people was engaged in this profession. The greatest part of the cloth, used to receive the colour in the state of thread, and the operation was most commonly performed by the weavers, but there were few houses of professed dyers in different parts of the province, who used to dye thread. They generally used indigo and lac as the dying materials. In some districts an indigenous variety of yellow dye was used which was extracted from fibers of the root of a tree called auch.

Flowering of cotton clothes with the needles was an important business connected with the cotton manufacture.

Now we consider the cotton textile industry of England where we see that the technology of production before and after the technological innovation were completely different. Here, prior to 1760 , the manufacture of textile occurred domestically where all members of the household played their part. Children were engaged in cleaning and carding the raw cotton and they assisted the weaver. Women spun the yarn and men wove the cloth. Cotton manufacturing was a subsidiary occupation to agriculture and except in Manchester, most of the weavers were also farmers. The process of production was tedious, inefficient and complicated. There was putting-out system where the merchants used to distribute the raw materials to the spinners and weavers. These merchants were scattered throughout the countryside.

The technology and production process of the cotton textile industry of England was more or less equal with the Bengal industry before the time when the English manufacturers endowed with many modern power driven machines which had come from the technological innovation. As Baines(Baines, 1835, p.115) mentioned that "up to the year 1760, the machines used in the cotton manufacture in England were nearly as simple as those of India; though the loom was more strongly and perfectly constructed, and cards for combing the cotton had been adopted from the woolen manufacture". All of its work was done, usually in the homes of the workers, occasionally in the small shops of the master weavers. Most of the fiber was being cleaned, carded and spun by hand. Of these pre-factory forms of organization, the weavers were independent with master often employed one or more journeymen or apprentices. However, as early as the thirteenth century - this independence broke down in many areas, and the artisan used to work under the merchants who supplied raw materials and collected the finished products (Habakkuk and Postan,1966, v.6, p.274-76). It was largely in this way that the production had 
come under the putting out system. In that time the cotton manufactures of England remained far away from the competition with Bengal's muslins and calicoes. As Orme (Orme,1805 , p.413), described "The women spin the thread designed for the cloths and then deliver it to the men, who have fingers to model it as exquisitely as these have prepared it. For it is a matter of fact that the tools which they used, was as simple and as plain as they can be imagined to be. The rigid clumsy fingers of a European would scarcely be able to make a piece of canvas with the instruments which are all an Indian employs in making a piece of cambric".

Now we consider the technology of production in England after technological innovation. The cotton industry of England was the industry which got revolutionary changes of technology and according to Rostow (Rostow, 1960, p.53) it was the 'original leading sector in the first takes off'. According to Schumpeter (Schumpeter,1939, v.I, p.271) "English industrial history (1778-1842) can be almost resolved into the history of a single industry'. The different technical inventions reshaped the production of cotton textiles. Among the early inventions Kay's flying shuttle, Paul's carding machine and Hargreave's spinning jenny were very important. Kay's flying shuttle was invented in 1730 and was used widely by the weavers in between 1750 to 1760 . Paul's carding machine was introduced in 1748 and was used in Lancashire about 1760. Hargreave's spinning - jenny was invented in 1764

Technological changes in the textile industry were started from early eighteenth century. However, these changes were not easily accepted by the workers of the cotton industry and gradual protests started from their corner. Machines made the works of the worker easier at every stage. It helped to save both time and energy and that why well accepted within a short period of time. John Kay's flying - shuttle enabled one weaver to do the work of two. Lewis Paul's spinner made spinning easier and efficient and it became more perfect by Arkwright's water frame. Hargreave's jenny enabled the spinner to spin dozens of threads simultaneously. These were the precursors of the inventive sprit and the application of new technology to the cotton textile industry.

In England at the 1760's, prizes were offered to encourage inventions which were very effective for new inventions. These technical inventions increased the productivity of the industry in a great extent. In that time the production of yarn by a single operator had increased many times. The mechanism of jenny was very simple and so a child could also operate it easily. The family spinning wheels were replaced by the jenny. From 1769, Arkwright water - frame caused revolution in the industry. By this, the British producers first produced strong cotton yarn by which they produced pure cotton cloth (i.e. without any linen mixture). The water - frame was operated by water and later by steam. In 1779, Crompton's mule was invented. From this time British producers had been able to produce smooth and finer yarn and the quality of cloth became so improved that it was able to compete with Bengal cloth. This was a great beginning of the cotton manufacture of England which started to outclass the Indian cotton cloth by their finer and stronger cloth in home as well as in the World market. The improvements in bleaching and dyeing were occurred by steam - powered machines.

After the technological innovation in England the production process of the two cotton production centers of the World became widely different. Bengal still used to produce with simple domestic implements and dominated by the cottage system of production which was concentrated in villages. But in England, whole character of the industry changed drastically through a great departure from the early domestic industry to a large factory system. By 1800 many cotton mills were built using the new technology. The spinning Mules provided strong and fine thread to the weavers. The weavers used to operate their looms by steam engines. Thus, the English industry had developed from a home - based cottage industry to a factory based industry housed in cotton mills. The wealthy merchant started to build mills for the production of cotton yarn and cloth and it became a profitable investment. These mills were mostly concentrated in three districts of England e.g in the North West England centered on Manchester, in the Midlands, centered on Nottingham and in the Clyde valley in Scotland between Lanark and Paisley. By 1780's the industry had become more concentrated in Lancashire with a large number of mills within the Oldham, Bolton and Manchester triangle. The spinners and the weavers were now the employees of the factory owners and no longer worked for themselves at home. The workers used to earn their income in the form of wage by rendering their labour for a specific period of time each day. In order to find work many people used to move into the areas where the cotton mills were located. The spinners and weavers now had been able to give up their agricultural activities and engaged themselves fully in cotton manufacture. The number of weavers increased considerably and they were concentrated in town. According to Radcliff, "from the year 1770 to 1788 a complete change had gradually been effected in the spinning of yarns. That of wool had disappeared altogether and that of linen was also nearly gone: cotton, cotton, cotton has become the almost universal material for employment." (Quoted Deane, 1994, p. 90).

Through the Industrial Revolution the cotton textile industry of England reached to the highest pick of development by the second quarter of the nineteenth century. Since then their large scale production made it possible to capture the home as well as World market and outclass the Bengal cotton goods. 
II

Before the Industrial Revolution and large scale factory system of production in England, the Bengal cotton textile industry was in advantageous position than its nearest rival i.e. the English cotton textile industry. Bengal possessed one of the major advantages of human capital due to its large population which gave her industry abundant supply of cheap labour whereas in England labour was costly. This comparative advantage caused the lower cost of production in Bengal than its rival. After the Industrial Revolution this comparative advantage of Bengal industry gradually shifted to England. After the Revolution, the Bengal industry was still run by labour - intensive indigenous production methods whereas the English industry used to apply labour saving method of production which caused the decrease of per unit labour - costs in England than in Bengal although the wages of labour was much higher in England. Here the above fact will be described with quantitative data.

Since the seventeenth century the Bengal piece goods flooded in the domestic market of Britain when its pattern and designs became fashionable to the people of England. The domestic textile producers of England became jealous and demanded protection. Baines (Baines, 1835, p.70) described that in seventeenth century the Dutch and the English East India Company imported Bengal muslin and calicoes in large quantities. As early as 1678 a loud outcry was made in England against the admission of Indian cotton goods to protect woolen industry. The cotton textile producer started to imitate the cotton manufacture of Bengal but they did not imitate the labour-intensive methods of production of Bengal because it was not possible to apply as wage was very high in England.

The cotton textile industry of England remained small in the seventeenth and even in the early decades of the eighteenth century. Because, the Bengal cotton goods were high in quality and low in price due to its lower average cost. A pamphlet of 1678 described that one men's coat made by Bengal calicoes was cheaper than of English one in English market by around 12d (Quoted Baines, 1835, p.71). Bengal had several advantages over other centers of textile production of which the most important was the abundance of cheap and highly skilled labour. The cost of living was low in Bengal due its developed agriculture and the prices of both food and cash crops were also low which permitted low wage as well as low cost of production. According to Chaudhury (Chaudhury, 1995, p.133) "This abundance of labour together with the cheapness of staples like rice, wheat and yarn automatically kept the production costs lower in Bengal than in other regions". This rural domestic handicraft industry of Bengal was runned by mostly of family labour where children and women besides their daily household work dedicated themselves in the industry without any remuneration which was a reason for lower cost of production. Many weavers used to took this profession adjacent to agriculture where agriculture was their prime profession. So, they did not care much on their earning from cotton manufacture or their lower wage did not discourage them. The fixed cost was very low because the construction cost of a loom was very low as it was built in wavers' own houses with the simplest possible low cost implements. This was an important reason for the low cost of production.

After the industrial revolution, the British cotton textile industry became endowed with modern machines for production. Due to the technological innovations and new factory system of production, the large scale production became possible. From 1766 to 1787 the cotton manufactures of England increased by 5.5 fold in value term. Before the period, the value of the cotton goods was 600,000 pound starling and it had become 3,304,371 pound starling in 1787 (Baines, op. cit. , p.218). In England, the per unit cost of production had declined after the large scale production.

Now we want to compare the labour cost of production between the two countries in the first half of the eighteenth century when English industry had become fully endowed with modern machines whereas the Bengal industry was still run by age old method of production. The labour cost of production will be analyzed by the following table

Table I The monthly wages of the spinners in different parts of Bengal

\begin{tabular}{|c|c|c|c|}
\hline Year & Kheerpoy Sa Rs.a.p & MaldaSa Rs.a.p & Radhanagar Sa Rs.a.p \\
\hline $1806-07$ & $3-0-0$ & $2-8-0$ & $3-0-0$ \\
\hline $1807-08$ & $3-0-0$ & $2-8-0$ & $3-0-0$ \\
\hline $1808-09$ & $3-0-0$ & $2-8-0$ & $3-0-0$ \\
\hline $1809-10$ & $3-0-0$ & $2-8-0$ & $3-0-0$ \\
\hline $1810-11$ & $3-0-0$ & $2-8-0$ & $3-0-0$ \\
\hline $1811-12$ & $3-0-0$ & $2-8-0$ & $3-0-0$ \\
\hline $1812-13$ & $3-0-0$ & $2-8-0$ & $3-0-0$ \\
\hline $1813-14$ & $3-0-0$ & $2-8-0$ & $3-0-0$ \\
\hline $1814-15$ & $3-0-0$ & $2-8-0$ & $3-0-0$ \\
\hline $1815-16$ & $3-0-0$ & $2-8-0$ & $3-0-0$ \\
\hline $1816-17$ & $3-0-0$ & $2-8-0$ & $3-0-0$ \\
\hline $1817-18$ & $3-0-0$ & $2-8-0$ & $3-0-0$ \\
\hline $1818-19$ & $3-0-0$ & $2-8-0$ & $3-0-0$ \\
\hline
\end{tabular}




\begin{tabular}{|l|l|l|l|}
\hline $1819-20$ & $3-0-0$ & $2-8-0$ & $3-0-0$ \\
\hline $1820-21$ & $3-0-0$ & $2-8-0$ & $3-0-0$ \\
\hline $1821-22$ & $3-0-0$ & $2-8-0$ & $3-0-0$ \\
\hline $1822-23$ & $3-0-0$ & $2-8-0$ & $3-0-0$ \\
\hline
\end{tabular}

Source: Progs B.O.T commercial, 29 ${ }^{\text {th }}$ June, 1827, vol. 453, Part II, No. 48

Table 2 Average Wage of Cotton Spinners in the Manchester District

\begin{tabular}{|l|l|l|l|}
\hline Year & Weekly Wages & Monthly wages & $\begin{array}{l}\text { Monthly wages } \\
\text { Sa Rs }\end{array}$ \\
\hline 1806 & 24s. 2d. & 96 s. 8d. & 44.6 \\
\hline 1810 & 30s. 2d. & 120 s. 8d. & 55.7 \\
\hline 1815 & 28s. 11d. & 112 s. 44d. & 53.4 \\
\hline 1819 & 27 s. 1d. & 108 s. 4d. & 50 \\
\hline 1833 & 22s. 0d. & 88 s. & 40.6 \\
\hline 1841 & 21s. 7d. & 84 s. 28d. & 39.8 \\
\hline 1849 & 24s. 1d. & 96s. 4d. & 44.5 \\
\hline
\end{tabular}

Source: Briggs, Economic History of England, p. 339.(Monthly wage in Sicca Rs(Sa Rs) is calculated on the basis of Exchange Rate between India and England which was 2s. 2d. per Sicca Rs in 1831 - 32 (HCPP 183132, v.10)

From the Table 1, the wages of the spinners in Bengal was nearly Sicca Rs 3 per month on average. From the Table 2, in England the wages of the spinner on average was 25s. 5 d. X $4=101 \mathrm{~s}$. 8d. or 47 sicca Rs per month. We see here that wage rate in Bengal was much lower than that of England in the first half of the nineteenth century. Montgomary Martin mentioned about the spinning cost to give answer to the questions of the members of the select committee which is as follows ............

Mr. Hogg. - Have you examined the comparative prices of spinning cotton in India and in England?

Mr. Martin.- In the documents laid before Parliament in 1832-33, there is a calculation given of the cost of labour of producing yarns in Britain and in India for one pound weight, from No. 40 to 250, and likewise of the value of the labour and material combined. Now this shows the great advantage in the cost of labour that England has over India. It shows that on yarn No.40, the cotton costs in England 1s. 6d., and the labour 1s., making $2 \mathrm{~s}$. $6 \mathrm{~d}$; but in India the cotton costs $3 \mathrm{~d}$. and the labour $3 \mathrm{~s}$. $4 \mathrm{~d}$.; the cost is therefore $3 \mathrm{~s}$. $7 \mathrm{~d}$.; on the next yarn spun, where the cost of labour in England is 1s. $6 \mathrm{~d}$., in India it is $5 \mathrm{~s} .8 .5 \mathrm{~d}$.; on the next yarn, where it is $2 \mathrm{~s}$. 2d. in England, it is 8s. 10.5d. in India: and in a similar manner the comparison proceeds through the different qualities of yarn, until upon yarn No.250, where the labour here is $31 \mathrm{~s}$., the labour in India is $83 \mathrm{~s}$. $4 \mathrm{~d}$ (HCPP 1840, v.8).

The productivity of the weavers in England was much higher than that of India. According to Martin, one weaver in England would produce more goods than six weavers in India (HCPP, ibid).

The prices of different cotton goods in England had declined and became lower than that of Bengal in the first half of the nineteenth century. The following Table shows the prices of different piece goods in England and in Bengal in 1818

Table 3 Comparative Prices of British and Bengal Piece Goods

\begin{tabular}{|c|c|c|}
\hline Description of the Articles & $\begin{array}{l}\text { Price } \\
\text { Made in England }\end{array}$ & $\begin{array}{l}\text { Price } \\
\text { Made in Bengal }\end{array}$ \\
\hline $\begin{array}{l}\text { Doreas } \\
\text { (20 yds. Piece) }\end{array}$ & Shilling & $\begin{array}{l}\text { Dacca }-155 \text { Shilling } \\
\text { Keerpoy }-45 \text { Shilling } \\
\text { Hurripaul }-89 \text { Shilling }\end{array}$ \\
\hline Cossaes & Shilling & $\begin{array}{l}\text { Malda \& } \\
\text { Dacca }-95 \text { Shilling }\end{array}$ \\
\hline Mulmuls & 22 to 35 Shilling & $\begin{array}{l}\text { Santipur }-47 \text { to } 76 \text { Shilling } \\
\text { Keerpoy }-39 \text { Shilling }\end{array}$ \\
\hline Nainsooks & Shilling & Keerpoy - 61 Shilling \\
\hline Seerhand- connees & 50 to 64 Shilling & $\begin{array}{l}\text { Dacca and } \\
\text { Santipore }-80 \text { to } 89 \text { Shilling }\end{array}$ \\
\hline
\end{tabular}

Source: Amales Tripathi, Trade and Finance in the Bengal Presidency, p.165.

Table 3 shows that the prices of different English piece goods were lower than that of Bengal.

In this section we see that in the first half of the nineteenth century the prices of English cotton goods had become lower than the Bengal piece goods. Although, the wages of labors was still lower markedly in Bengal than that in England. So, we say that prices of English cotton goods reduced due to the high productivity and large scale factory production which were the fruits of Industrial Revolution in Great Britain. Here we can 
mention that "the cheapest Hindu labour could not compete either in quality or quantity with Lancashire's mules or throsteles" (Habakkuk and Postan, op. cit., p.275).

\section{III}

The facts described in this article shows that the period under review represented economically an important phase when Industrial Revolution caused a drastic change of the production system in England whereas the Bengal industry still follow the traditional age old system of production. In this period a gradual collapse of the cotton industry of Bengal occurred and the cotton industry of England which remained far from the competition with the Bengal industry for a long time had come in the leading position.

Here we have analyzed the technological factor which should be judged to find out the main cause for the victory of English cotton goods over the Bengal muslin and calicoes. We had discussed the labour cost of production after industrial revolution also. The labour cost of production after the Industrial Revolution in England had become lower than that of Bengal although the wage rate was very high in England.

If, we consider the oppression on Bengal weavers in one hand and tariff protection to English cotton industry on the other hand, we see that after tariff policy and oppression the Bengal cotton textile industry remained in buoyant position more than hundred years. So, this factor was not very significant.

So, the oppression and the prohibitive tariff ware not the leading factors for the decay of the Bengal industry. Although, these certainly had some prejudicial effects on the Bengal cotton industry. The point is that even if there had been no hostile tariffs and no oppression the defeat of the Bengal industry could not have been prevented long on account of the mighty force set in motion by the mechanical revolution. It was Industrial Revolution, which enabled England to supplant the Bengal cotton manufactures not only outside, but within our own country itself. Improvements and inventions of machinery made it possible by the British industry to produce muslin and calicoes in imitation of the Bengal at such lower prices so that it enabled to surpass the Bengal cotton producers both in terms of prices and quality.

So, the technological innovation in Great Britain was the main cause which led to the decay of the prosperous and glorious cotton industry of Bengal.

\section{References}

[1]. N,K. Sinha, The Economic History of Bengal ( Calcutta, Firma K.L.M., 1961)

[2]. R. Dutta, The Economic History of India under Early British Rule, vol.1 (New Delhi: Govt. of India, 1960, first published by Kegan Paul, Trench, Trubner \& Co., London, in 1901).

[3]. M.J Twomay, Employment in $19^{\text {th }}$ century Indian Textile, Explorations in Economic History 20, P. 37-57, 1983.

[4]. E. Baines, History of Cotton Manufacture in Great Britain (London, H Fisher, R Fisher and P. Jackson, 1835)

[5]. W. Ward, A View of the History, Literature and Mythology of the Hindoos, vol. I ( Serampore, Mission Press, 1818)

[6]. J. Taylor, A sketch of the topography and statistics of Dacca (Calcutta, Military Orphan Press, 1840)

[7]. H. J. Habakkuk and M. Postan, (ed.), The Cambridge Economic History of Europe, vol. VI, (Cambridge University Press, 1966)

[8]. R. Orme, Historical Fragments of the Mogul Empire (London, F. Wingrave, 1805)

[9]. W. W. Rostow, Stages of Economic Growth: A non-communist Manifesto (Cambridge University Press, 1960)

[10]. J. A. Schumpeter, Business Cycle, A theoretical, historical and statistical Analysis of the capitalist process( New York, Toronto, London, Mc Graw-hill Book Company, 1939)

[11]. P.M. Deane, The first industrial revolution ( Second Ed., published in India in 1994, New Delhi, originally published by Cambridge University Press in 1965, Second Ed. in 1979)

[12]. S. Chaudhury, From Prosperity to Decline: Eighteenth Century Bengal ( New Delhi, Manohar, 1995)

[13]. Proceeding, Board Of Trade commercial, 29 ${ }^{\text {th }}$ June, 1827, vol. 453, Part II, No. 4.

[14]. M. Briggs, Economic History Of England (London, University Tutorial Press, 1914)

[15]. HC (1831 - 32), British Parliamentary Papers, vol. 10.

[16]. HC (1840), British Parliamentary Papers, vol. 8.

[17]. A. Tripathi, Trade and Finance in the Bengal Presidency (Orient Longmans Bombay Calcutta Madras, 1956) 